J. Asiat. Soc. Bangladesh, Sci. 43(1): 71-81, June 2017

\title{
EFFECTS OF SLUMS ON ECOSYSTEM COMPONENTS
}

SARAFAT HOSSAIN, TAZEEN FATIMA KHAN AND S.M. IMAMUL HUQ *

Department of Soil, Water and Environment, University of Dhaka, Dhaka-1000, Bangladesh

\begin{abstract}
An in vitro study was conducted to assess the effects of slums on ecosystem services particularly soil, plant and water. The research findings indicated that, samples of soil, plant and water were contaminated with heavy metals, many of which were above permissible limits. The heavy metals exceeding the permissible limits pose serious threats to the surrounding plant and animal lives. Hence, there is a health risk associated with the consumption of the vegetables grown in the slums due to the fact that the heavy metals can bio-accumulate into human body through the food chain.
\end{abstract}

Key words: Slums, Ecosystem, Heavy metal, Bio-accumulation, Food chain

\section{Introduction}

Bangladesh is one of the most densely populated countries in the world with more than 160 million people living in a territory of around 56,977 sq. miles. One quarter of the population lives in urban areas, where population density is 200 times greater than the national figure and population growth is twice the national average (BBS 2011). Millions of slum-dwellers in Bangladesh live stressful lives among teaming rubbish because there is no or little waste disposal system. In these areas where wastes have been dumped without coverage, the soil will contain high amounts of pollutants. Industrial wastes originating from mining industries, chemical industries, metal processing industries etc. are major sources of soil contamination. These wastes include a variety of chemicals like heavy metals, phenols etc. (Babich and Stotzky 1977 and Mueller et al. 1989). Above certain concentrations and over a narrow range, the heavy metals turn into toxins (Babich et al. 1982). Moreover, the heavy metals deposited in the soil are bound preferentially to inter-aggregate soil materials and accumulation preferentially occurs in parts of the soil where plant roots are concentrated and in the forms that are easily accessible to plants (Wagner 1993). However, plants can absorb heavy metals in larger amounts than needed and the excessive amount will be stored in leaves and other edible parts. Through food consumption theses metals are then transferred to humans and animals. A high intake of heavy metals can damage organs and increase the risk of human cancer (Martin and Griswold 2009). Thus, the present study was conducted to assess the effects of slum areas on ecosystem components viz., soil, plant and water.

\footnotetext{
*Corresponding address: E-mail: imamhuq@ hotmail.com
} 


\section{Materials and Methods}

Soil, plant and water samples were collected from different slums in Dhaka city and were analyzed in the laboratory to find out the contents of nutrients and heavy metals.

\section{Collection, preparation and processing of soil, plant and water samples}

Soil Sampling: A total of eight soil samples was collected from four different slum areas of Dhaka city namely Kalyanpur, Gabtoli, Baunia and Sadek Khan. Table 1 shows the geographical coordinates of the sampling sites. The soils belong to Tejgaon series, which is mostly red, sticky, slightly acidic, clayey-loam having low to moderately low $\mathrm{pH}$ values (Hussain 1992). Soil samples representing 0-15 cm depth were collected by composite sampling method as suggested by the Soil Survey Staff of the USDA (1951). The collected soil samples were oven dried for 5 days. Visible roots and debris were removed. The samples were exposed to sunlight for speeding up the drying process. Ground samples were passed through a $2 \mathrm{~mm}$ sieve and mixed thoroughly. A portion ofthe soil samples ( $2 \mathrm{~mm}$ sieved) were further ground and screened to pass through a 0.5 $\mathrm{mm}$ sieve. The homogenized samples were used for physico-chemical analyses.

Table 1. Geographical coordinates of the sampling sites.

\begin{tabular}{cccc}
\hline Sampling Site & Symbol & Latitude & Longitude \\
\hline Kalyanpur & K & $23^{\circ} 47^{\prime} 032^{\prime \prime} \mathrm{N}-23^{\circ} 47^{\prime} 033^{\prime \prime N}$ & $90^{\circ} 21^{\prime} 432^{\prime \prime} \mathrm{E}-90^{\circ} 21^{\prime} 448^{\prime \prime} \mathrm{E}$ \\
Gabtoli & $\mathrm{G}$ & $23^{\circ} 46^{\prime} 815^{\prime \prime} \mathrm{N}-23^{\circ} 46^{\prime} 921^{\prime \prime} \mathrm{N}$ & $90^{\circ} 20^{\prime} 405^{\prime \prime} \mathrm{E}-90^{\circ} 20^{\prime} 474^{\prime \prime} \mathrm{E}$ \\
Baunia & $\mathrm{B}$ & $23^{\circ} 49^{\prime} 093^{\prime \prime} \mathrm{N}-23^{\circ} 49^{\prime} 161^{\prime \prime} \mathrm{N}$ & $90^{\circ} 22^{\prime} 976^{\prime \prime} \mathrm{E}-90^{\circ} 23^{\prime} 000^{\prime \prime} \mathrm{E}$ \\
Sadek Khan & SK & $23^{\circ} 44^{\prime} 952^{\prime \prime} \mathrm{N}-23^{\circ} 44^{\prime} 969^{\prime \prime} \mathrm{N}$ & $90^{\circ} 21^{\prime} 516^{\prime} \mathrm{E}-90^{\circ} 21^{\prime} 543^{\prime \prime} \mathrm{E}$ \\
\hline
\end{tabular}

Plant samples: A total of 28 plant samples was collected from three different slum areas namely Kalyanpur, Gabtoli, Baunia. The plant was uprooted and processed for laboratory analyses as suggested by Imamul Huq and Alam (2005). After collection, the whole plant was washed in tap water. Different plantparts were separated and were rewashed thrice with distilled water. These plant samples were first air-dried and then oven-dried (80 $85^{\circ} \mathrm{C}$ ), grounded and finally sieved through a $0.25 \mathrm{~mm}$ sieve.

Water samples: The water samples were collected by Grab and Catch method from different sources of wells and ponds of the slum areas (Imamul Huq and Alam 2005).Few drops of concentrated $\mathrm{HCl}$ were added to the bottle in order to acidify the samples. Then the bottle was filled with water samples for chemical analyses following filtration.

Laboratory analysis of soil and plant samples: The quality control and quality assurance (QC/QA) of the analyses were done as described in Imamul Huq et al. (2008). Nitrogen in bothsoil and plant was determined by alkali distillation of the Kjeldahl digests (Imamul Huq and Alam 2005). Phosphorous was determined following colorimetric method using a spectrophotometer and potassium by a flame photometer (Jackson 1962). Organic carbon was determined by Walkley and Black's wet oxidation method (Imamul Huq and 
Alam 2005) The heavy metals were analyzed by using Atomic Absorption Spectrophotometer (Varian AA 240) after digesting the samples with aqua-regia (for soil) and ternary acid mixture (for plants).

Data analysis: All data were statistically analyzed by using Microsoft Excel and MINITAB (version 17) package.

\section{Results and Discussion}

Nutritional status of soil and plant samples: Contents of nitrogen, phosphorous, potassium and organic matter in soil were determined (Figs. 1 to 3 ). The nitrogen of the soils was found to be insignificant as compared to the standard value (Fig. 1a). However, the available nitrogen was found to be higher compared to that of the standard value (Fig. 1b). The available phosphorous in the soil (Fig. 2b) was not significant except one sample (Sadek Khan) although the total phosphorous (Fig. 2a) was higher than the standard limit set for soil. The soils contained less potassium than the standard value for both soil and plant (Figs. 3a and 3b). The organic matter of the soils in the slums were mostly around $1 \%$ except the soil of Sadek Khan sampling site which possessed around $3.1 \%$ organic matter.

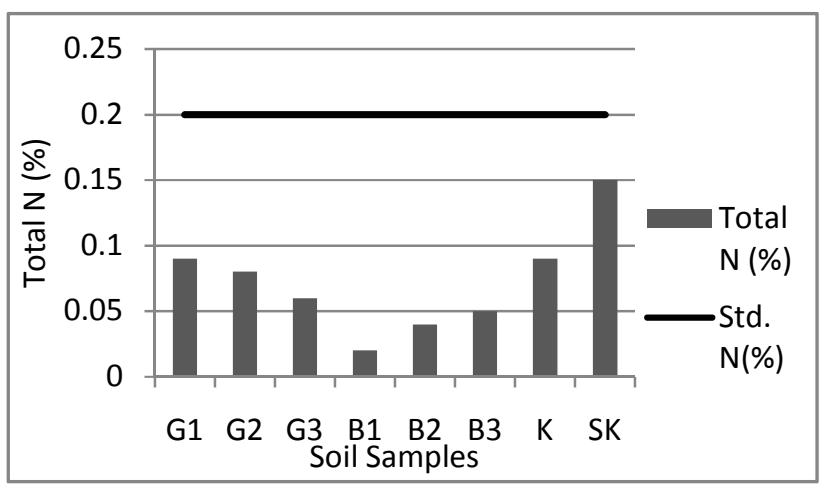

Fig. 1(a). Total Nin soils.

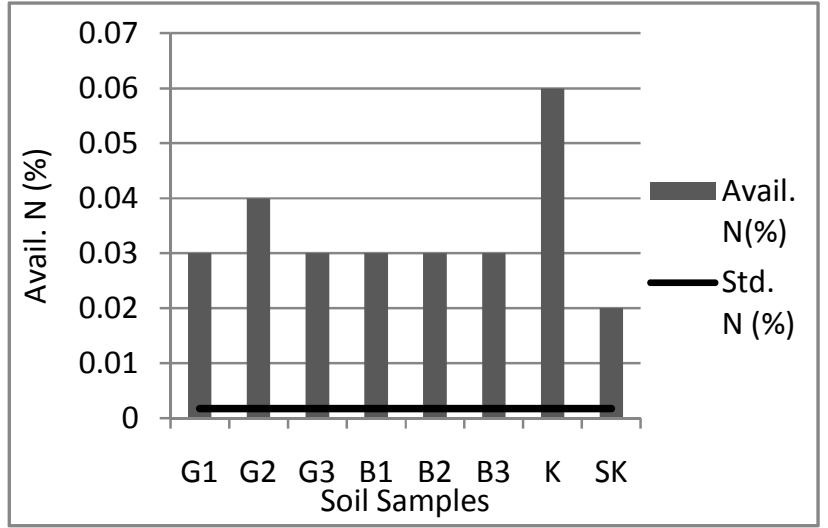

Fig. 1(b). Available $\mathrm{N}$ in soils. 


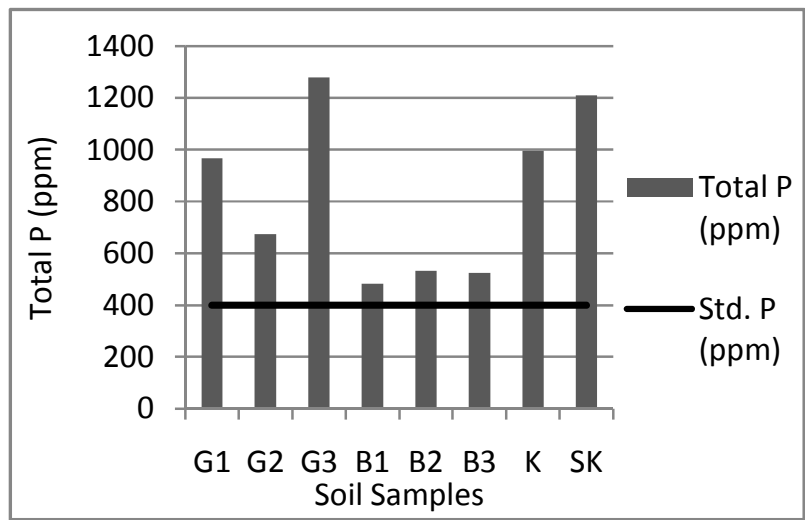

Fig. 2(a). Total P in soils.

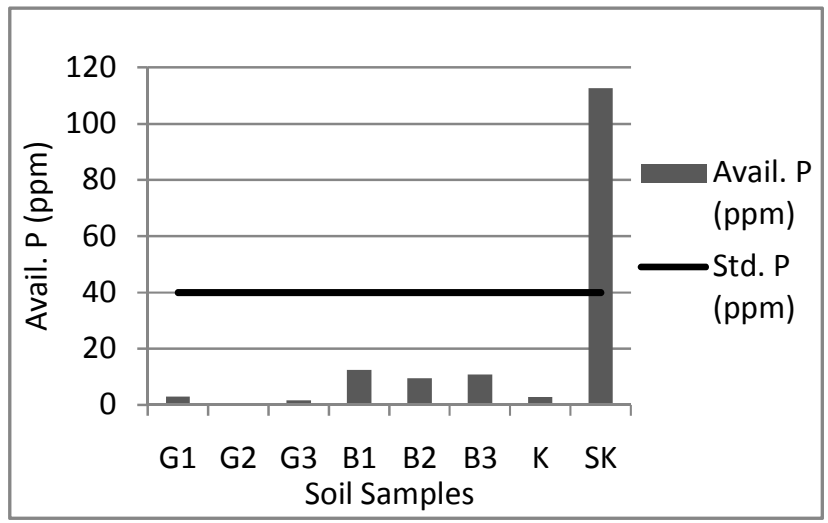

Fig. 2(b). Available P in soils.

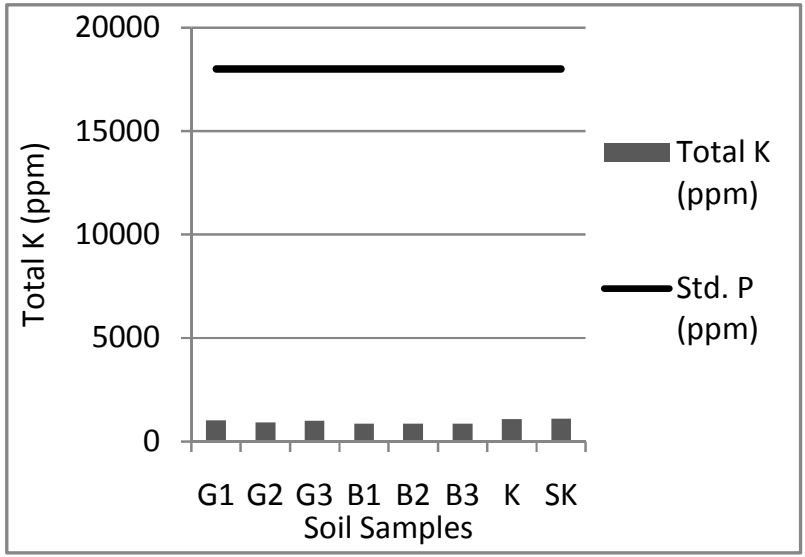

Fig. 3(a). Total $\mathrm{K}$ in soils. 


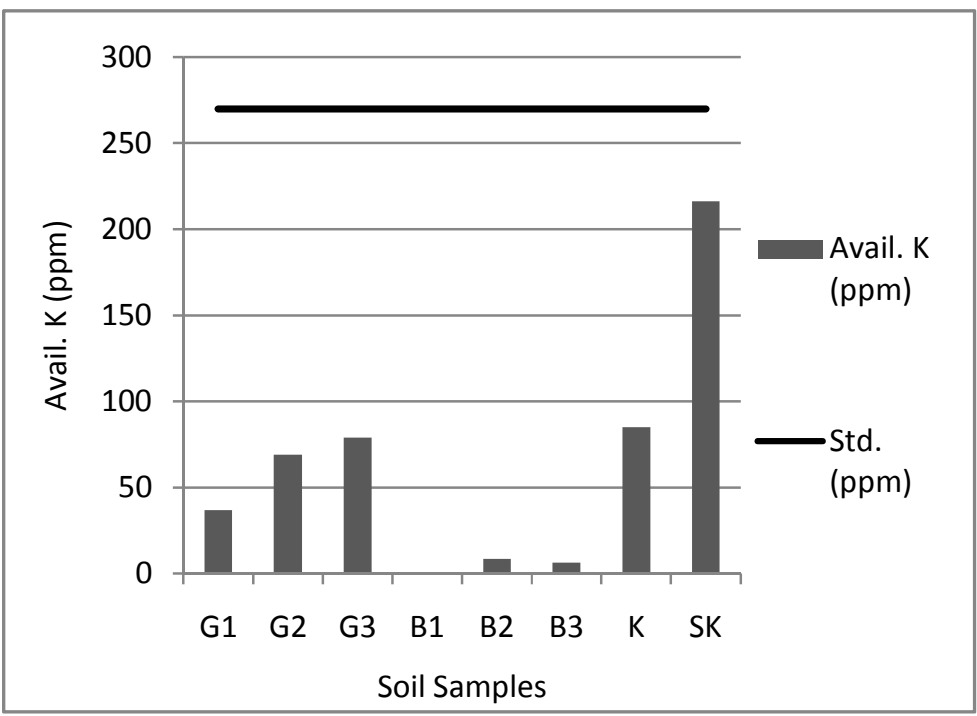

Fig. 3(b). Available K in soils.

Heavy metals in soils and plants: Contents of heavy metals ( $\mathrm{Pb}, \mathrm{Cr}, \mathrm{As}, \mathrm{Zn}, \mathrm{Mn}$ and $\mathrm{Al})$ recorded in soils and plants are presented in Figs. 4 to 9.

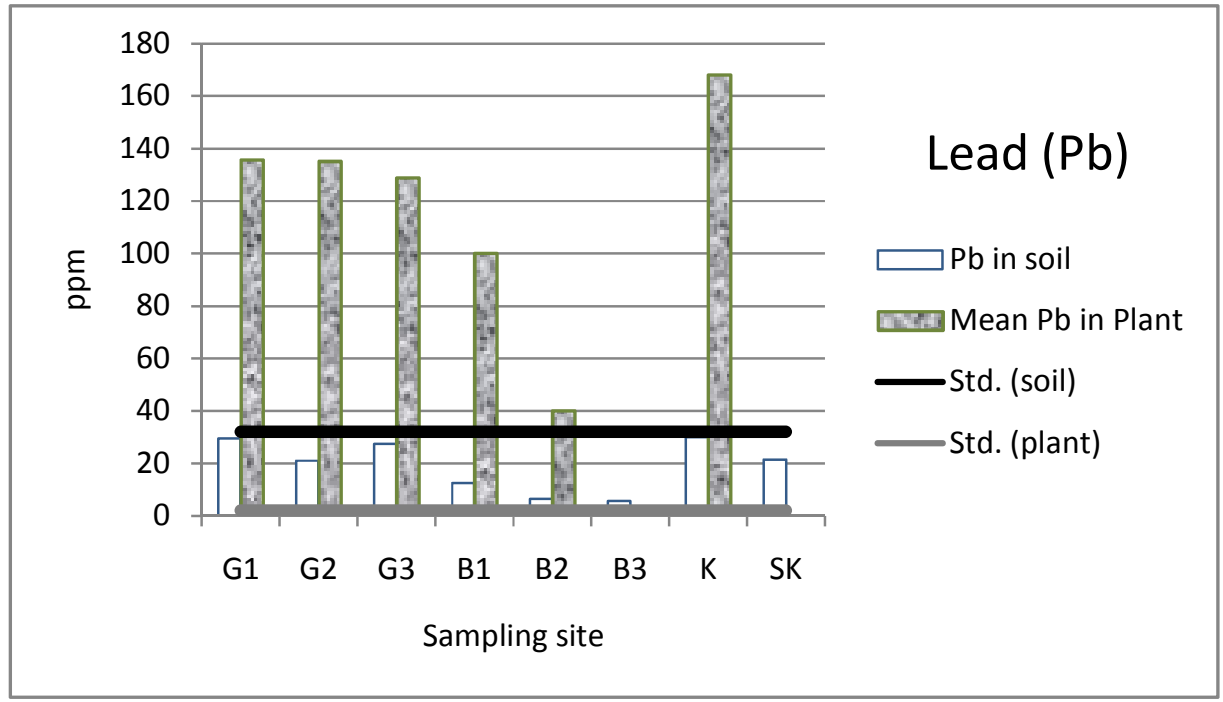

Fig. 4. Concentration of lead $(\mathrm{Pb})$ in soils and plants. 


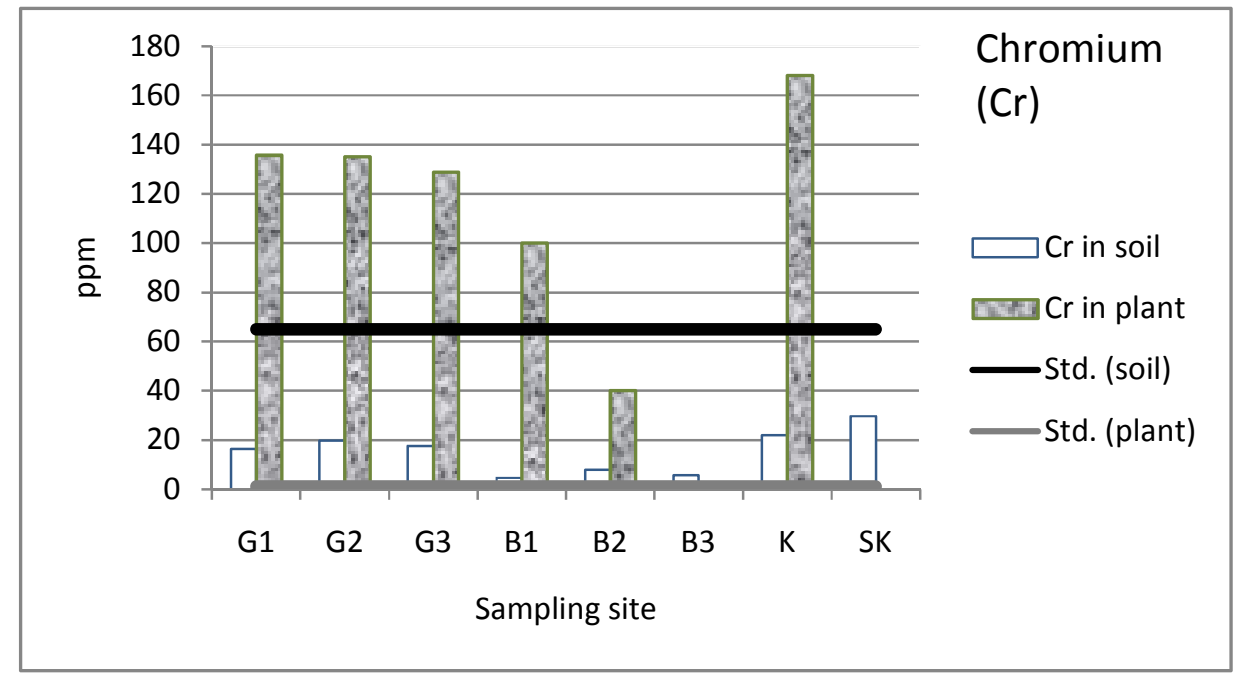

Fig. 5. Concentration of chromium $(\mathrm{Cr})$ in soils and plants.

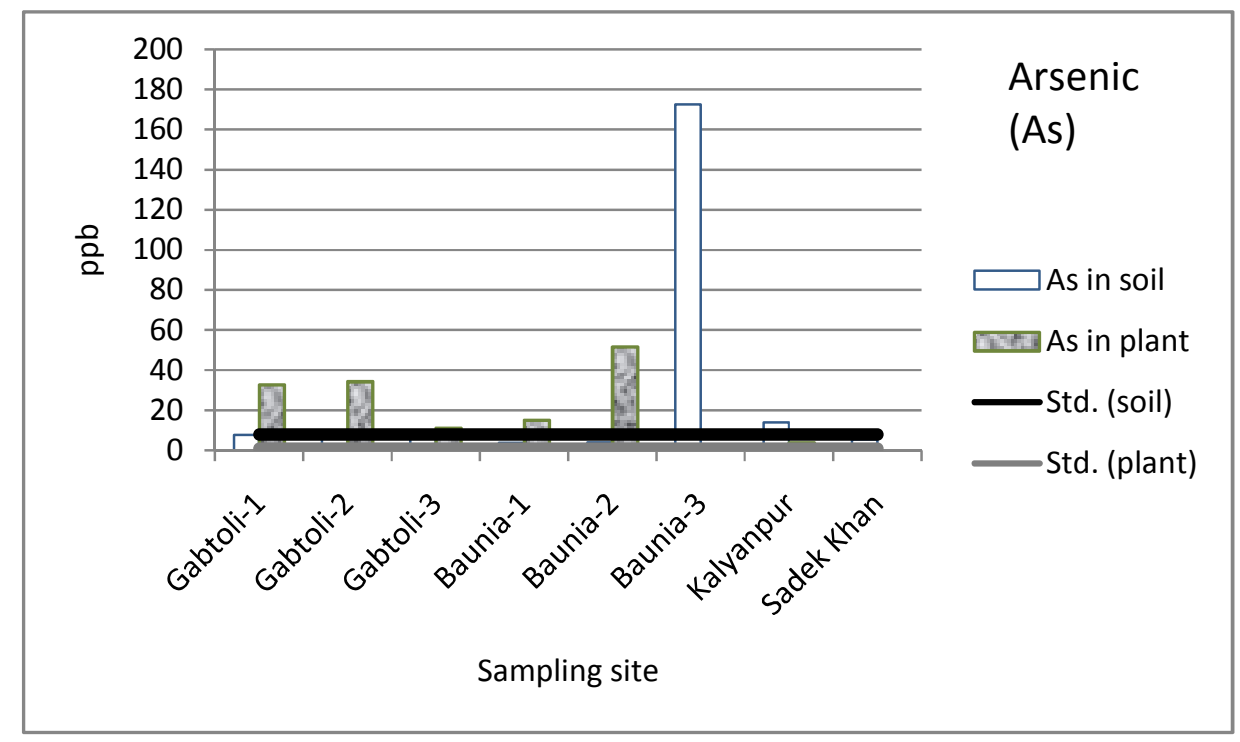

Fig. 6. Concentration of arsenic (As) in soils and plants. 


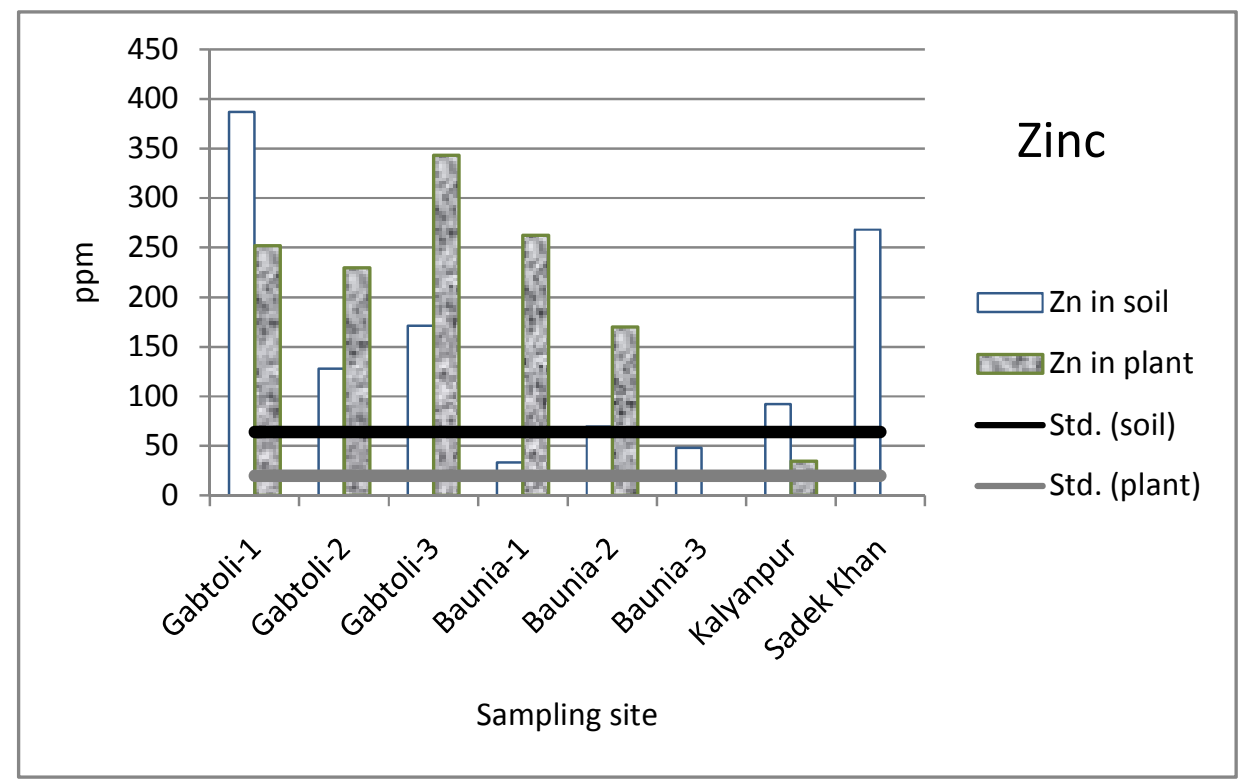

Fig.7. Concentration of zinc (Zn) in soils and plants.

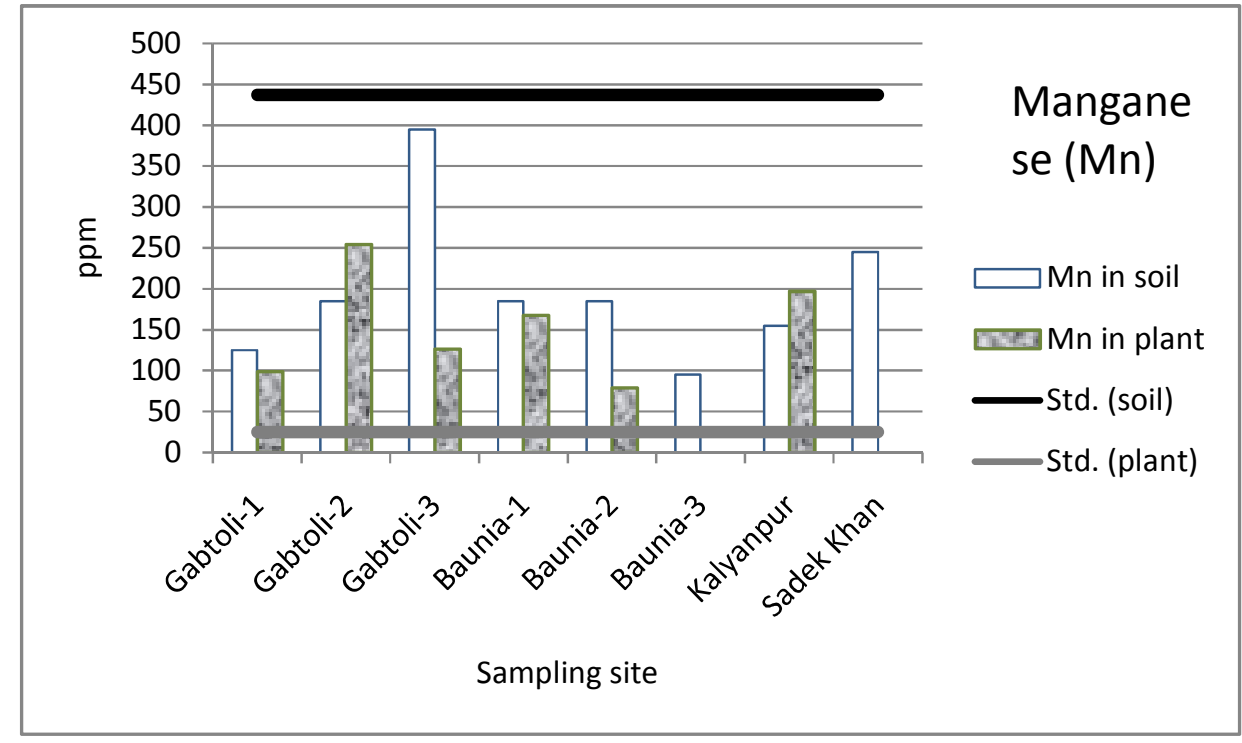

Fig. 8. Concentration of manganese (Mn) in soils and plants. 


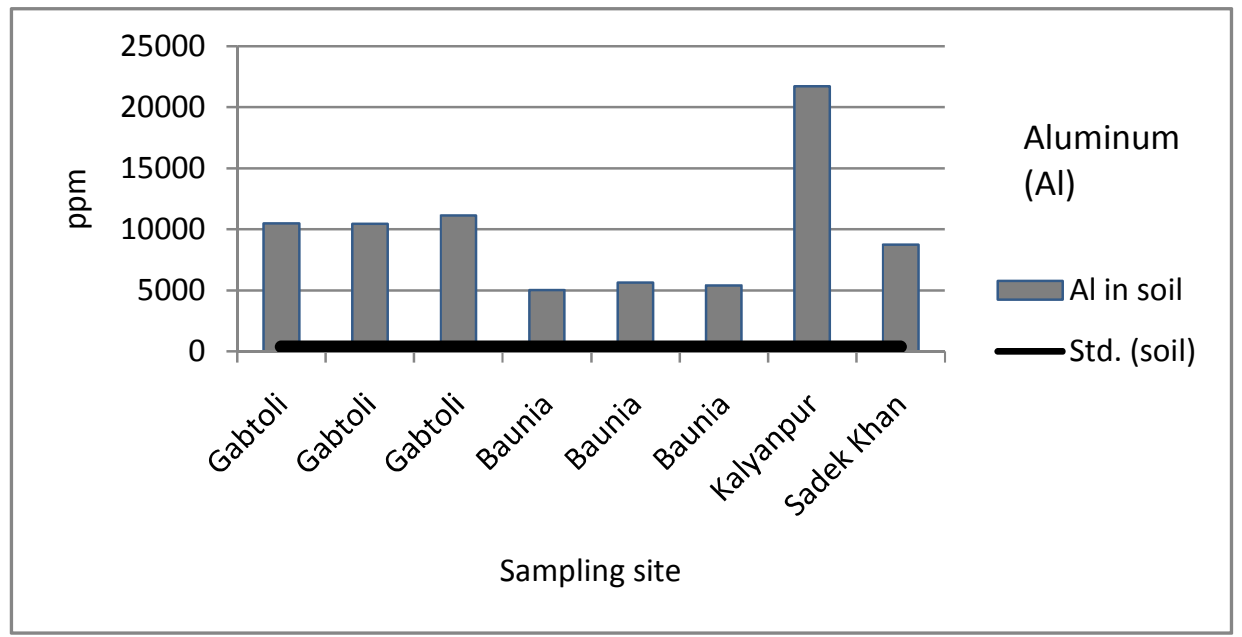

Fig. 9. Concentration of aluminum $(\mathrm{Al})$ in soils and plants.

Table 3 shows that heavy metals viz., $\mathrm{Cd}, \mathrm{Al}, \mathrm{As}$ and $\mathrm{Fe}$ in water bodies were present in excessive amounts as compared to the standard limits for irrigation purpose. Manganese (Mn) was present in moderate level. However, $\mathrm{Cr}$ and $\mathrm{Zn}$ were found below the standard limits. This indicates that there is a possibility for plants to uptake heavy metals from the water used for irrigation purpose, which would further aggravate the situation.

Table 3. Total heavy metals contents in irrigation water.

\begin{tabular}{lllllllll}
\hline \multicolumn{1}{c}{ Water samples } & $\mathrm{Zn} *$ & $\mathrm{Mn}^{*}$ & $\mathrm{~Pb}^{*}$ & $\mathrm{Cd}^{*}$ & $\mathrm{Cr}^{*}$ & $\mathrm{Al}^{*}$ & $\mathrm{As}^{*}$ & $\mathrm{Fe}^{*}$ \\
\hline Gabtoliwater sample & $\mathrm{BDL}$ & 0.25 & 0.42 & 0.07 & 0.07 & 33.79 & 0.00614 & 126.84 \\
Bauniawater sample & $\mathrm{BDL}$ & 0.22 & 0.35 & 0.09 & 0.06 & 34.34 & 0.00581 & 79.63 \\
Kalyanpurwater sample & $\mathrm{BDL}$ & 0.17 & 0.73 & 0.06 & 0.09 & 35.69 & 0.00536 & 78.27 \\
\hline
\end{tabular}

*values are in $\mathrm{mg} / \mathrm{L}$; BDL= Below Detection Level

It is apparent from the Figs. 4 to 9 that plants grown in slum areas contained more heavy metals compared to that of the corresponding soils. However, there was an excessive amount of aluminum (Al) in soils which might initiate soil acidity if the $\mathrm{pH}$ drops below 5.2 (Brady and Weil 2002).Almost all of the plant biomasses contained very high amounts of lead $(\mathrm{Pb})$, which was present in the edible parts (fruit, leaf and shoot) and thus could be transferred through food chain in human body. The highest concentrations were found in soils and plants of Kalyanpur area (Fig. 4).

All of the plants contained chromium $(\mathrm{Cr})$ much higher than the Maximum Allowable Concentration (MAC) and cannot be considered safe. The highest concentration of $\mathrm{Cr}$ was found in soils of Kalyanpur site and plants of Sadek Khan site (Fig. 5).Soils of 
Baunia-3 site showed extremely high concentration of As and no plants were found to grow in this site. However, plants growing in Gabtoli-1, Gabtoli-2 and Baunia-2 contained As in amounts exceeding the upper limit, making it impossible to consume these plants (Fig. 6).

Nutritional status of plant samples: The plants contained sufficient amount of $\mathrm{N}$ and $\mathrm{K}$ (Table 2). But the phosphorous content of the plants was found to be below the standard level i.e. 2000 ppm (Imamul Huq and Alam 2005). This may happen partly because the soils contained lower amounts of available phosphorous.

Table 2. Total N, P, K contents in plants.

\begin{tabular}{|c|c|c|c|}
\hline Sampling Site/ Plant Sample & $\begin{array}{l}\text { TotalN } \\
(\%)\end{array}$ & $\begin{array}{l}\begin{array}{l}\text { Total P } \\
(\mathrm{ppm})\end{array} \\
\end{array}$ & $\begin{array}{l}\begin{array}{l}\text { Total K } \\
(\mathrm{ppm})\end{array} \\
\end{array}$ \\
\hline \multicolumn{4}{|l|}{ Kalyanpur site } \\
\hline Papaya (Carica papaya) (Leaf) & 2.39 & 1468.15 & 17840.0 \\
\hline Sweet potato (Ipomoea batatas) & 1.74 & 1567.92 & 14140.0 \\
\hline Gourd (Lagenaria siceraria) & 3.36 & 1640.83 & 15940.0 \\
\hline Bean (Phaseolus vulgaris) & 2.58 & 1721.41 & 13540.0 \\
\hline Tomato (Solanum lycopersicum) & 1.21 & 1429.78 & 15440.0 \\
\hline Arum & 1.43 & 1778.97 & 16840.0 \\
\hline \multicolumn{4}{|l|}{ Gabtoli site-1 } \\
\hline Red amaranth (Amaranthus gangeticus) (Leaf) & 1.71 & 1295.47 & 13140.0 \\
\hline Red amaranth (Amaranthus gangeticus) (Shoot) & & 1541.06 & 25940.0 \\
\hline Tomato (Solanum lycopersicum) (Leaf) & 3.13 & 1729.09 & 14540.0 \\
\hline Tomato (Solanum lycopersicum) (Root) & & 1587.11 & 9740.0 \\
\hline Tomato (Solanum lycopersicum) (Shoot + Fruit) & & 1706.06 & 18940.0 \\
\hline Bean (Phaseolus vulgaris) (Shoot + Leaf) & 3.00 & 1276.29 & 11440.0 \\
\hline Gourd (Lagenaria siceraria) (Shoot) & 4.27 & 1495.01 & 22940.0 \\
\hline Gourd (Lagenaria siceraria) (Leaf) & & 1345.36 & 14940.0 \\
\hline \multicolumn{4}{|l|}{ Gabtoli site-2 } \\
\hline Red amaranth (Amaranthus gangeticus) (Leaf + Root) & 2.85 & 1552.57 & 25640.0 \\
\hline Green amaranth (Amaranthus viridis) (Leaf + Shoot) & 2.70 & 1775.13 & 15040.0 \\
\hline Tomato (Solanum lycopersicum) (Leaf + Root) & 1.92 & 1175.13 & 8640.0 \\
\hline \multicolumn{4}{|l|}{ Gabtoli site-3 } \\
\hline Indian spinach (Basella alba)(Leaf + Shoot) & 0.57 & 1844.21 & 9340.0 \\
\hline Gourd (Lagenaria siceraria) (Shoot + Leaf) & 2.28 & 1717.58 & 18040.0 \\
\hline Green amaranth (Amaranthus viridis) (Shoot + Root) & 3.84 & 2055.23 & 13340.0 \\
\hline Green amaranth (Amaranthus viridis) (Leaf) & & 1544.90 & 15540.0 \\
\hline \multicolumn{4}{|l|}{ Baunia site-1 } \\
\hline Indian spinach (Basella alba) & 1.21 & 1782.81 & 17240.0 \\
\hline Gourd (Lagenaria siceraria) (Leaf) & 1.71 & 1890.25 & 11440.0 \\
\hline Gourd (Lagenaria siceraria) (Shoot) & & 1778.97 & 17140.0 \\
\hline Bean (Phaseolus vulgaris) (Leaf + Shoot) & 2.56 & 1932.46 & 11240.0 \\
\hline \multicolumn{4}{|l|}{ Baunia site-2 } \\
\hline Red amaranth (Amaranthus gangeticus) (Leaf + Root) & 4.00 & 1610.13 & 16040.0 \\
\hline Red amaranth (Amaranthus gangeticus) (Stem) & & 1425.94 & 20840.0 \\
\hline Green amaranth(Amaranthus viridis) (Shoot + Root) & 3.84 & 2055.23 & 13340.0 \\
\hline Green amaranth (Amaranthus viridis) (Leaf) & & 1544.90 & 15540.0 \\
\hline
\end{tabular}


The amounts of zinc $(\mathrm{Zn})$ and manganese $(\mathrm{Mn})$ in plants were found in amounts higher than the standard value. Fig. 8 shows that the highest concentration of Mn was found in the soils of Gabtoli-3 and plants of Gabtoli 2. However, the maximum concentration of $\mathrm{Zn}$ was found in the soils of Gabtoli 1 and plants of Gabtoli 3.

The $\mathrm{pH}$ values of the top soils were between 5.22 and 6.70, which might make the heavy metals available for the growing plants. Figs. 4 to 9 illustrate that the soils contained smaller concentration of heavy metals than plants alone did. This indicates that, there might be another source of heavy metals from which plants are taking them up. It could be water with which the soils were irrigated or the fertilizers which were applied to the soils to meet the nutritional deficiencies. However, if the $\mathrm{pH}$ decreases in soil, more metals are expected to be released and become available for plant uptake as the soil buffers the acidity.

It is observed from Figs. 4 to 9 that the soils in the slum areas contained heavy metals in varying concentrations; some of them were present at toxic levels. In case of plants, the scenario was quite different. These figures illustrate that almost all the plants grown in slums contained excessive amounts of heavy metals. $\mathrm{Pb}, \mathrm{As}, \mathrm{Cr}, \mathrm{Zn}$ and $\mathrm{Mn}$ were present in all kinds of plant biomass (edible parts) at a toxic concentration which,if consumed for long period may contribute to carcinogenic diseases in human body.

Adverse effects of slums on the ecosystem are one of the burning questions of today's modern world. The present study provided a precise idea about the contents of nutrient elements and heavy metals present in soil, plant and water of different slum areas. The results confirmed that both the soils and plants in all slum areas contained high concentration of heavy metals exceeding the permissible limits that ultimately led to decreased agricultural crop production. The high concentration of heavy metals in soil might become readily available to the plants that could aggravate health risks of the slum dwellers. In addition, nitrogen, phosphorous and potassium contents were found to be less compared to those of the standard values. Water collected from various sources of slum areas did not meet the acceptable limit for irrigation. Thus, it is pertinent to assess the pollution level of soil, plant and water present in and around the slum areas. Further detailed study is needed regarding the type and magnitude of the treatments for these polluted components of ecosystem.

\section{Acknowledgements}

The authors are grateful to Manchester University of England, Dhaka University, BRAC University as well as ICDDR,B for their financial support in conducting the present study. 


\section{References}

Babich, H. and G. Stotzky. 1977. Effect of cadmium on fungi and on interactions between fungi and bacteria in soil: Influence of clay minerals and pH. Appl. Environ. Microbiol. 33: 1059-1066.

Babich, H., M. Schiffenbauer and G. Stotzky. 1982. Comparative toxicity of trivalent and hexavalent chromium to fungi. Bull. Environ. Contam.Toxicol. 28: 193-202.

BBS. 2011. Statistical Yearbook of Bangladesh. Bangladesh Bureau of Statistics. Ministry of Planning, Government of the People's Republic of Bangladesh, Dhaka. 55-56 pp.

Brady, N. C. and R. R. Weil. 2002. The nature and properties of soils. $13^{\text {th }}$ edition, Pearson Education Inc., New Jersey, USA. 20 pp.

Hussain, M. S. 1992. Soil classification with special reference to the soils of Bangladesh. Dhaka University Press, Dhaka, Bangladesh. 338-362 pp.

Imamul Huq, S. M.and M. D. Alam. 2005. A handbook on analyses of soil, plant, and water. Bangladesh-Australia Centre for Environmental Research (BACER-DU), University of Dhaka, Bangladesh. pp. xxii - 246.

Imamul Huq, S. M., S. Al-Mamun, J. C. Joardar and S. A. Hossain. 2008. Remediation of soil arsenic toxicity in Ipomea aquatica using various sources of organic matter. Land Contam. Reclam.16: 333-341.

Jackson, M. L. 1962. Soil chemical analysis. Prentice Hall Inc., Englewood Cliffs, New Jersey, USA. 1 - 498 pp.

Martin, S. and W. Griswold. 2009. Human health effects of heavy metals, environmental science and technology briefs for citizens. Center for Hazardous Substance Research, Kansas State University, USA.4-5 pp.

Mueller, J. G., P. J. Chapman and P. H. Pritchard. 1989. Creosote contaminated sites. Environ. Sci. Technol. 23: 1197-1201.

USDA. 1951. Soil Survey Manual by Soil Survey Staff. United States Department of Agriculture. Bureau of Plant Industry. Soils and Agricultural Engineering Handbook No. 18.205 pp.

Wagner, G.J. 1993. Accumulation of cadmium in crop plants and its consequences to human health. Adv. Agron. 51: 173-212. 